\title{
SIMULTANEOUS REMOVAL OF ZINC, COPPER AND COBALT FROM CONTAMINATED SOILS BY BIOSURFACTANT
}

(Received: 8. 10. 2012)

\author{
By \\ M.M.S. El-Shahad, W.D.Saleh and M.Z. Sedik \\ Microbiological Department, Faculty of Agriculture, Cairo University, Giza, Egypt
}

\begin{abstract}
A biosurfactant-producing bacterium isolated from clay soils was investigated for its effects on the plant growth characteristics and heavy metal removal. A pot experiment was conducted for investigating the capability of the biosurfactant-producing bacterial strain Rhodococcus sp. to improve the plant growth and zinc, copper and cobalt uptake of tomato in soil artificially contaminated with different levels of $\mathrm{Zn}$, $\mathrm{Cu}$ and $\mathrm{Co}\left(50 \mathrm{ppm} \mathrm{kg}^{-1}\right.$ for each element).

Data revealed that bacilli gave a highly percentage of the bacterial isolates $(38.7 \%)$ followed by micrococci group (34.4\%). While, short rods Gram negative presented $16.1 \%$ of the total isolates. Moreover, both of the long rods Gram positive and filaments bacteria presented 5.4\%, respectively.

The morphological characteristics of pure isolates indicated that Gram positive presented $84.2 \%$ of the total isolates. While, the Gram negative represented (15.8\%) from the total isolates.

Thirty three isolates were tested for biosurfactant production. Only 6 isolates had potential to degrade the diesel oil after 3 to 5 days with a different degree of degradation.

The percentage of the height of emulsified layer $(\mathrm{cm})$ after 3 and 5 days of incubation period of the selected six isolates showed that isolate Sm2-4 gave the highest emulsification percentage (91\%) after 3 days of incubation period. While isolates Sm1-1, Sm2-3 and Sm2-8 gave the lowest emulsification \% reached $71 \%$ after 3 days. Both of the two isolates number Sm2-12 and Sm2-9 recorded the second category of emulsification percentage and reached $88 \%$ after 3 days of incubation period.

Growth parameters of tomato plants grown for 60 days after treatment with heavy metals and bacterial treatments were studied. At the beginning, tomato plants of all treatments nicely grew with no nutrient deficiency symptoms.

Plants of less than $26 \mathrm{~cm}$ in height were detected with a plant left without treatment (control). Recommended fertilizers N, P, and K stimulated plant growth and resulted in $38.4 \%$ increase in height of 60-day-old plants. While, plants fertilized with the recommended dose of NPK, inoculated with Rhodococcus $\mathrm{sp}$. and treated with a mixture of $\mathrm{Co}, \mathrm{Cu}$ and $\mathrm{Zn}$ sulphate 15 days after planting gave 57.1\% increase in plant height when compared with untreated ones.

Root sizes ranged from 2.2 to $6.8 \mathrm{~cm}^{3}$ depending on treatment and plant age-dependent.

Root and shoot biomass yields increased as a result of inoculation and / or heavy metal treatment. When Rhodococcus sp. and heavy metal salts (50 ppm concentration) were applied in the presence of full dose of NPK root and shoot dry weights were 84.2 and 193.3\% higher than those of the control. Also, when Rhodococcus sp. and heavy metals were applied 15 days after planting, root and shoot dry weights were 118.4 and $222.1 \%$ higher than those of the untreated ones.

Tomato plants bore considerable number of leaves. Plenty of those ( 83 and 92 per plant) was produced by plants received full dose of recommended fertilizers together with incorporation into soil of the tested dose of three heavy metals.
\end{abstract}

Keywords: biosurfactant, Rhodococcus sp., Zn, CU, Co, tomato.

\section{INTRODUCTION}

Surfactants are amphiphilic compounds containing both hydrophilic and lipophilic moieties. Due to their dual nature, surfactants tend to partition into the oil-air or oil-water interface to reduce the surface and interfacial tension and stabilize newly created interfaces. Surfactants can be derived from both chemically based ("chemical surfactants" or "synthetic surfactants") and biologically based (biosurfactants) sources 
(Urum and Pekdemir, 2004 and Qingyi et al., 2011).

Many microorganisms have the ability to produce a wide range of biosurfactants. An initial classification of biosurfactant was made into two types; based on molecular weights, properties and cellular localizations. The low molecular weight biosurfactants e.g. glycolipids, lipopeptides, flavolipids, corynomycolic acids and phospholipids lower the surface and interfacial tensions at the air/water interfaces. High molecular weight ones are called bioemulsans, (such as emulsan, alasan, liposan, polysaccharides and protein complexes) and are more effective in stabilizing oil-in-water emulsions (Neu, 1996, Franzetti et al., 2009 and Salihu et al., 2009).These high molecular weight biosurfactants are highly efficient emulsifiers that work at low concentrations and exhibit considerable substrate specificity (Dastgheib et al., 2008 and Salihu et al., 2009).

Biosurfactant producing microorganisms can be used in bioremediation and oil leak clearance in soil and water environments (Head and Swannell, 1999; Mulligan, 2005; Urum et al., 2006 and Ghayyomi Jazeh et al., 2012).

Contamination of soil environments with heavy metals is very hazardous for human and other living organisms in the ecosystem. Due to their extremely toxic nature, the presence of even low concentrations of heavy metals in the soil has been found to have serious consequences. Nowadays, there are many techniques used to clean up soils contaminated with heavy metals. Remediation of these soils includes non biological methods such as excavation, and disposal of contaminated soil to landfill sites or biological techniques (Aşçı et al., 2010 and PacwaPłociniczak et al., 2011).

Biological methods are processes that use plants (phytoremedation) or microorganisms (bioremediation) to remove metals from the soil. The two following methods, soil washing or soil flushing, are involved in remediation of metal contaminated soil. The first technique used is $e x$ situ contaminated soil is excavated, put into the glass column and washed with biosurfactant solution. In turn, soil flushing of in situ technologies involves use of drain pipes and trenches for introducing and collecting biosurfactant solution to and from the soil (Herman et al., 1995; Singh and Cameotra, 2004 and Pacwa-Płociniczak et al., 2011).
Previous work with Rhodococcus sp. has shown that the strain could produce biosurfactants and mobilize a mixture of zinc, copper and cobalt efficiently in the soil. However, research to determine the potential effect of Rhodococcus sp. on the growth of tomato in mixture of $\mathrm{Zn}, \mathrm{Cu}$ and Co-amended soils has not been performed.

The major objectives of this research were to isolate and characterize the biosurfactantproducing Rhodococcus sp. Also, to evaluate the enhancement of plant growth improvement and $\mathrm{Zn}, \mathrm{Cu}$ and $\mathrm{Co}$ uptake in tomato plants grown in $\mathrm{Zn}, \mathrm{Cu}$ and $\mathrm{Co}$-amended soil for improving the efficiency of bioremediation of $\mathrm{Zn}, \mathrm{Cu}$ and Copolluted soils.

\section{MATERIALS AND METHODS}

2.1. Soil samples

Ten soil samples were collected from six different sites in Giza and Ismailia Governorates. Three clay soil samples were collected at a depth of $10 \mathrm{~cm}$ from the Experimental Station of the Faculty of Agriculture, Cairo University and another three sandy-clay soils collected from private farms in Kerdasa Village, Giza. In addition, four sandy soil samples were collected from Ismailia Governorate.

\subsection{Bacterial isolates}

Serial dilution aliquots were used for the inoculation of the culture media. Enrichment and isolation of bacterial isolates were performed using nutrient agar medium. The plate cultures were incubated at $30^{\circ} \mathrm{C}$ for $24-48$ hours (Khan and Syed, 2011). Ninety five isolates were collected from the soil samples. Streak plate procedure, complied by Grainger et al. (2001)was used. Selected isolates were transferred to fresh medium until identification and classification carried out. The isolates were purified by streaking plate procedure on nutrient agar medium and studied for morphological characters and biochemical tests.

\subsection{Identification of bacteria}

Colonies were selected from agar plates according to their morphological characteristics which include colony size, colony consistency, colony color, Gram staining and the motility tests.

\subsection{Biochemical tests}

The biochemical tests were applied on pure culture according to the tests recorded by Sneath (1984).

\subsection{Biosurfactant activity}

Thirty three isolates were tested for biosurfactant production by inoculating them in nutrient broth medium incubated at $30^{\circ} \mathrm{C}$ for 24 
hours. After incubation period $1 \mathrm{ml}$ of diesel oil was added into culture tubes and incubated at $30^{\circ} \mathrm{C}$ for 2-7 days.

Emulsification index (E24) was used for measuring and detecting the best isolates producing biosurfactant (Sarubbo, 2006). The E24 of six strains was measured by adding $2 \mathrm{ml}$ of diesel oil and $2 \mathrm{ml}$ of the broth culture in a test tube, vortexes at $380 \mathrm{ppm}$ for $2 \mathrm{~min}$ and incubated for 5 days. The percentage of emulsified layer was calculated by the formula.

E24 = Height of emulsion formed x $100 /$ Total height of the solution.

The E24 index is given as a percentage of the height of emulsified layer $(\mathrm{cm})$.

\subsection{Heavy metal resistance}

The best six bacterial isolates (Sm1-1, Sm2-3, Sm2-4, Sm2-8, Sm2-9 and Sm2-12) which gave the highest emulsion layer were accomplished for resistance test in nutrient broth supplemented with three heavy metals in salt form $(\mathrm{Cu}, \mathrm{Zn}$ and $\mathrm{Co}$ sulfate) with three concentrations for each heavy metal salt (25 ppm, $50 \mathrm{ppm}$ and $100 \mathrm{ppm})$. The more resistant isolate (Sm2-4) was inoculated in broth culture medium supplemented with three heavy metals and incubated at $30^{\circ} \mathrm{C}$ for $24-48$ hours. Another experiment was done by using nutrient agar medium supplemented with a mixture of heavy metals with the same last concentrations inoculated with the bacterial isolate ( $\mathrm{Sm} \mathrm{2-4)}$ by streaking method and incubated at $30^{\circ} \mathrm{C}$ for 24 hours.

\subsection{Application of biosurfactant in pot experiment Soil}

The soil used in bioremediation of heavy metals ( $\mathrm{Zn}, \mathrm{Cu}$ and $\mathrm{Co})$ by biosurfactant producing bacterial isolate was collected from the farm of the Faculty of Agriculture, Cairo University, Giza. Soil was characterized by: sand, $38.6 \%$; silt, $19.6 \%$; clay, $27.0 \%$; WHC, $28 \%$; $\mathrm{pH}, 7.4$; EC, $0.67 \mathrm{dSm}^{-1}$; total carbon, $0.58 \%$ and total nitrogen, $0.05 \%$ (Jackson, 1973). The soils were air dried and crushed to pass $2 \mathrm{~mm}$ sieve. Plastic pots of $30 \mathrm{~cm}$ diameter and $25 \mathrm{~cm}$ depth were filled with $8 \mathrm{~kg}$ of sandy loam soil: peat mixture $(1: 1 \mathrm{w} / \mathrm{w})$.

Twenty one day old tomato seedlings (Solanum lycopersicum); kindly provided by the Vegetable Crops Department, Faculty of Agriculture, Cairo University; were planted at the rate of 3 seedlings $\operatorname{pot}^{-1}$. Heavy metals $(\mathrm{Zn}, \mathrm{Cu}$ and $\mathrm{Co}$ ) were incorporated into the experimental pots in levels equivalent to $50 \mathrm{ppm}$ for each metal as sulfate salts.

For bacterial inoculation, the best isolate characterized by high production of biosurfactant was separately grown in nutrient broth for one week. An aliquot of $5.0 \mathrm{ml}$ of the bacterial inoculum was added over head soil adjacent to the seedling root system, this was done at planting.

A pot experiment was designed to improve tomato growth via biosurfactant produced by the best isolate inoculated in the soil contaminated with a mixture of heavy metals. The experimental design encompassed four treatments as follows; 1 ) untreated plants, 2) fully-NPK received plants, 3) fully NPK received plants supplemented with the best bacterial and mixture of $\mathrm{Zn}, \mathrm{Co}$ and $\mathrm{Cu}(50$ ppm) and 4) fully NPK received plants supplemented with the best isolate and a mixture of the last three heavy metals 15 days after planting. Application of the recommended doses of NPK fertilizers was done as nitrogen in the form of ammonium sulphate $(20.6 \% \mathrm{~N})$; and PK fertilization regimes as $500 \mathrm{~kg} \mathrm{fed}^{-1}$ and $400 \mathrm{~kg}$ $\mathrm{fed}^{-1}$ of calcium superphosphate and potassium sulphate, respectively. The nitrogen fertilizer was added at three equal levels after 7,15 and 21 days of transplanting. Inoculation with the best isolate was performed by adding an aliquot of $5.0 \mathrm{ml}$ of the bacterial inoculum over head soil adjacent to the seedling root system of 21-day old tomato seedlings in heavy inoculum of $>10^{8}$ cell ml-1. Plantation, incorporation into the soil of the fertilizers, inoculation with biosurfactant producing bacterial culture, irrigation and sampling procedures were applied as pot experiment.

The applications of heavy metals were applied in two sets of pot experiments. In the first set, heavy metals $(\mathrm{Zn}, \mathrm{Cu}$ and $\mathrm{Co})$ were introduced at planting. While in the other; the ( $\mathrm{Zn}, \mathrm{Cu}$ and $\mathrm{Co})$ were incorporated into the soil 15 days after seedling establishment. These pot experiments were designed to clarify the effect of bioremediation of $\mathrm{Zn}, \mathrm{Cu}$ and $\mathrm{Co}$ by biosurfactant as well as the vegetable growth in the soil inoculated with the best isolate. The adopted potting mixture facilitates an appropriate root establishment and plant standing.

Along the experimental period of 60 days, plants were watered to keep the moisture level at ca. $60 \%$ WHC. An additional inoculum was added at 15-day intervals. Four treatments were allocated for either vegetable plant in triplicates.

\subsection{Statistical analysis}

Data were statistically analyzed by least 
significant difference (Snedecor and Cochran, 1980) as well as correlations and linear regressions among different growth variables.

\section{RESULTS AND DISCUSSION}

Ten soil samples were collected from two governorates for the isolation and screening of bacterial isolates producing biosurfactant. Ninety five bacterial isolates were isolated and purified.

Data obtained indicated that the majority of the isolates displayed a colony size less than $1.0 \mathrm{~cm}$. Also, the consistency was ranged between aqua to rough in most bacterial isolates. Colony color, was creamy, yellow, white, brown and white brown.

The morphological characteristics of the purified isolates represented five forms of bacteria i.e. spore-forming, micrococci, short rods G-, long rods $\mathrm{G}+$ and filamentous bacteria. Data in Table (1) and Figure (1) reveal that spore-forming bacteria represented the highest percentage of the bacterial isolates $(38.7 \%)$ followed by micrococci group $(34.4 \%)$. While, short rods Gram negative represented $(16.1 \%)$ of the total isolates. Long rods Gram positive and filamentous bacteria represented $5.4 \%$, respectively. turbidity as well as sediment in their broth culture media. Also, $20 \%$ of the total pure isolates was giving a pellicle.

The Gram staining results of pure isolates are presented in Fig. (2). The results indicated that the Gram positive presented $(84.2 \%)$ of the total isolates. While the Gram negative represented $(15.8 \%)$ from the total isolates.

The motility test showed that $57.9 \%$ of the total isolates were motile but the rest were not motile (Fig. 3).

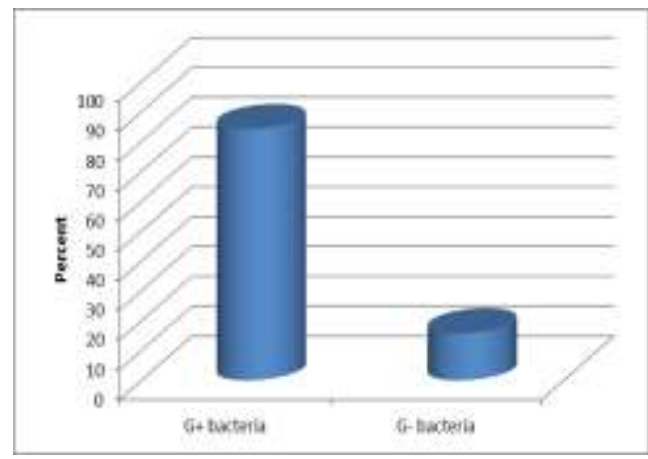

Fig. (2): Gram staining percentage of the bacterial isolates.

Table(1): Number and form of bacterial isolates of each soil sample tested

\begin{tabular}{|l|c|c|c|c|c|c|}
\hline \multirow{2}{*}{$\begin{array}{c}\text { Sample } \\
\text { No. }\end{array}$} & \multirow{2}{*}{$\begin{array}{c}\text { No of } \\
\text { Isolate. }\end{array}$} & $\begin{array}{c}\text { Spore- } \\
\text { forming }\end{array}$ & Micrococci & $\begin{array}{c}\text { Short rod } \\
\mathbf{G}^{-}\end{array}$ & $\begin{array}{c}\text { Long rod } \\
\mathbf{G}^{+}\end{array}$ & $\begin{array}{c}\text { Filaments } \\
\text { bacteria }\end{array}$ \\
\hline Sm1 & 10 & 5 & - & 3 & - & 2 \\
\hline Sm2 & 12 & 4 & 4 & 3 & 1 & - \\
\hline Sm3 & 11 & 2 & 6 & 3 & - & - \\
\hline Sm4 & 8 & 3 & 3 & 2 & - & - \\
\hline Sm5 & 7 & 2 & 2 & 1 & 1 & 1 \\
\hline Sm6 & 8 & 4 & 3 & - & - & 1 \\
\hline Sm7 & 12 & 5 & 4 & 2 & 1 & - \\
\hline Sm8 & 8 & 3 & 4 & 1 & - & - \\
\hline Sm9 & 10 & 5 & 3 & - & 1 & 1 \\
\hline Sm10 & 9 & 4 & 4 & - & 1 & - \\
\hline Total Isolates & 95 & 37 & 33 & 15 & 5 & 5 \\
\hline
\end{tabular}

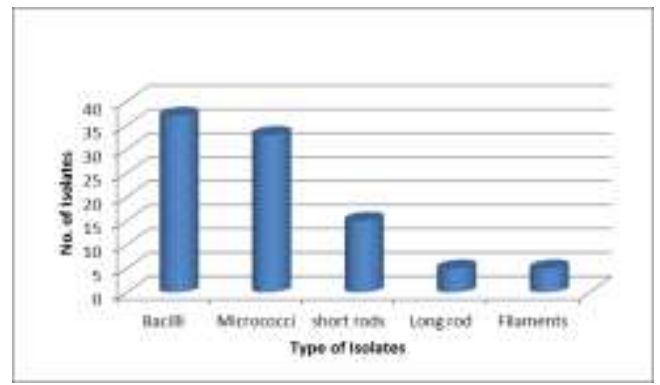

Fig. (1): Distribution of bacterial isolates isolated from ten soil samples.

The growth of pure isolates on nutrient broth showed that more than $50 \%$ of the isolates gave a

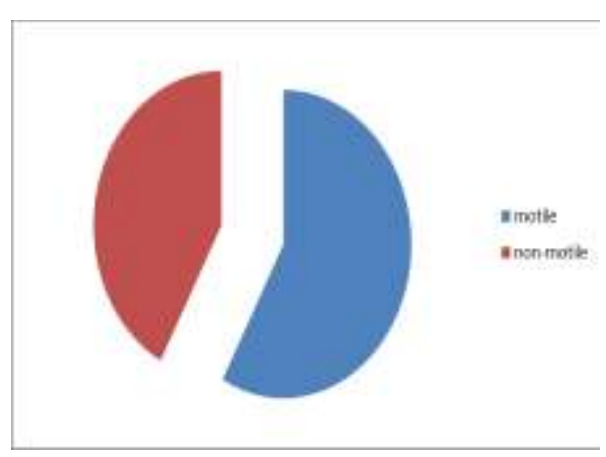

Fig. (3): Percentage distribution of motile and non-motile bacterial isolates. 


\subsection{Biochemical tests}

Data presented in Table (2) showed the results of biochemical tests for the selective and chosen isolates. with the same percentage of decrease.

The best isolate (Sm2-4) for the production of biosurfactant was classified according to Brenner et al. (2005). The classification results were

Table (2): Biochemical tests of the selective bacterial isolates.

\begin{tabular}{|c|c|}
\hline Form & Tests and results \\
\hline Spore-forming bacteria & $\begin{array}{l}\text { Club shape, spore, large, strict aerobe, catalase }(+) \text {, V.P. }(+) \text {, cell } \\
\text { diameter } \geq 1 \mu \mathrm{m} \text {, citrate }(+) \text {, growth in } 6.5 \% \mathrm{NaCl}(+) \text {, starch } \\
\text { hydrolysis }(+) \text {, glucose fermentation }(+) \text { and mannitol fermentation }(+) \text {. }\end{array}$ \\
\hline Long rod, non- spore form & $\begin{array}{l}\text { Club shape, non-spore, branching, rudimentary, catalase (-), acid fast (- } \\
\text { ), oxidase test (-) and Hugh Lefson test (+). }\end{array}$ \\
\hline Short-rods form & $\begin{array}{l}\text { Short rod, Gram (-), motile, non-spore, oxidase }(+) \text {, indole }(+) \text {, methyl } \\
\text { red }(+) \text {, catalse }(+) \text {, urease }(+) \text { and glucose fermentation }(-) \text {. }\end{array}$ \\
\hline Cocci form & Round and oval shape, $\mathrm{Gram}^{+}$, non-motile, \\
\hline Filamentous shape & $\begin{array}{l}\text { Branching filaments, Gram (+), irregularly size elements, non-motile, } \\
\text { flagellate spore, gelatin slowly liquefied, Indole }(+) \text {, starch hydrolysis } \\
(+) \text { and nitrate hydrolysis }(+) \text {. }\end{array}$ \\
\hline
\end{tabular}

\subsection{Biosurfactant activity}

Thirty three isolates were tested for biosurfactant production (Sarubbo,2006). Only 6 isolates had potential to degrade the diesel oil after 3 to 5 days with a different degree of degradation (Table 3). Isolates Sm 2-4 gave the highest degradation of motor oil after 3 and 5 days of incubation period. While, two isolates only ( $\mathrm{Sm} 2-$ 9 and Sm2-12) gave very good results of degradation after the same period. Moreover, the three isolates (Sm1-1, Sm2-3 and Sm2-8) gave a pass result. On the other hand, the rest of the total isolates (27 isolates) was not able to degrade the diesel oil after 3 and 5 days of incubation periods. recorded in Table (6) and Fig.(4).

According to the morphological and biochemical tests carried out, the best isolate proved to be Rhodococcus sp.

\subsection{Resistance to heavy metals}

The best bacterial isolate (Rhodococcus sp.) which gave the highest emulsion layer was accomplished for resistance to heavy metal test in nutrient broth supplemented with three heavy metals in salt form ( $\mathrm{Cu}, \mathrm{Zn}$ and Co sulfate) with three concentrations for each heavy metal salt (25 ppm, $50 \mathrm{ppm}$ and $100 \mathrm{ppm}$ ). The cultural medium supplemented with heavy metals was inoculated by bacterial isolate $(\mathrm{Sm} 2-4)$ and incubated at $30^{\circ} \mathrm{C}$ for 24-48 hours. It was found that the Sm2-4

Table (3): Degree of degradation of the diesel oil of the thirty three isolates after 3 days.

\begin{tabular}{|l|c|c|c|c|c|c|}
\hline Isolate number & Sm1- 1 & Sm2-3 & Sm2- 4 & Sm2-8 & Sm2-9 & Sm2-12 \\
\hline Degradation diesel oil & $1+$ & $1+$ & $5^{+}$ & $1+$ & $3^{+}$ & $3^{+}$ \\
\hline
\end{tabular}

Pass (+), Very good (3+) and Excellent (5+).

The percentages of the height of emulsified layer $(\mathrm{cm})$ after 3 and 5 days of incubation period of the selected six isolates are presented in Tables (4 and 5). The results showed that isolate Sm2-4 gave the highest emulsification percentage (91\%) after 3 days of incubation period. While, isolates number Sm1-1, Sm2-3 and Sm2-8 gave the lowest $\%$ and reached $71 \%$ of emulsification $\%$ after 3 days. Both isolates number Sm2-9 and Sm2-12 gave the second category of emulsified percentage which reached $88 \%$ after three days of incubation period. While, the increasing of the incubation period to 5 days led to decreasing the emulsification percentage in all isolates tested isolate can grow in a culture medium supplemented with $25 \mathrm{ppm}$ and $50 \mathrm{ppm}$ of $\mathrm{Zn}$ and $\mathrm{Co}$ sulfate. While in a medium containing $\mathrm{Cu}$ sulfate the isolates can grow only in $25 \mathrm{ppm}$. While, in a culture medium supplemented with a concentration of $100 \mathrm{ppm}$ of the three heavy metals, the bacterial isolate failed to grow (Table 7).

These results are in agreement with the data obtained by Sheng et al. (2008)who, reported that biosurfactant was found to exhibit different multiple heavy metals $(\mathrm{Pb}, \mathrm{Cd}, \mathrm{Cu}, \mathrm{Ni}$ and $\mathrm{Zn})$. 
Table (4): Emulsification layer (\%) of the six pure isolates after 3 days of incubation period.

\begin{tabular}{|c|c|c|c|c|}
\hline No. of isolates. & $\begin{array}{c}\text { Height of } \\
\text { emulsification layer } \\
\text { (cm /Culture) }\end{array}$ & $\begin{array}{c}\text { Height of diesel } \\
\text { oil layer }(\mathbf{c m} \text { ) }\end{array}$ & $\begin{array}{c}\text { Total height of } \\
\text { solution }(\mathbf{c m})\end{array}$ & $\begin{array}{c}\text { The \% of } \\
\text { emulsification } \\
\text { layer (E24) }\end{array}$ \\
\hline Sm1-1 & 2 & 0.5 & 2.5 & 80 \\
\hline Sm2-3 & 1.5 & 0.6 & 2.1 & 71 \\
\hline Sm2-4 & 2.1 & 0.2 & 2.3 & 91 \\
\hline Sm2-8 & 2.2 & 0.3 & 2.5 & 88 \\
\hline Sm2-9 & 2.2 & 0.3 & 2.5 & 88 \\
\hline$S m 2-12$ & 1.5 & 0.4 & 1.9 & 79 \\
\hline
\end{tabular}

Table (5): Emulsification layer (\%) of the six pure isolates after 5 days of incubation period.

\begin{tabular}{|c|c|c|c|c|}
\hline No. of isolates & $\begin{array}{c}\text { Height of } \\
\text { emulsification layer } \\
\text { (cm / Culture) }\end{array}$ & $\begin{array}{c}\text { Height of diesel } \\
\text { oil layer }(\mathbf{c m})\end{array}$ & $\begin{array}{c}\text { Total height of } \\
\text { solution (cm) }\end{array}$ & $\begin{array}{c}\text { The \% of } \\
\text { emulsification } \\
\text { layer (E24) }\end{array}$ \\
\hline Sm1-1 & 1.9 & 0.6 & 2.5 & 76 \\
\hline Sm2-3 & 1.4 & 0.7 & $2-1$ & 67 \\
\hline Sm2-4 & 2.0 & 0.3 & 2.3 & 87 \\
\hline Sm2-8 & 1.9 & 0.4 & 2.3 & 83 \\
\hline Sm2-9 & 1.9 & 0.4 & 2.3 & 83 \\
\hline Sm2-12 & 1.6 & 0.5 & $2-1$ & 76 \\
\hline
\end{tabular}

Table (6): Morphological and biochemical results of the best isolate (Sm2-4).

\begin{tabular}{|l|c|}
\hline Characteristics & Result \\
\hline Cell shape & Rodo- cocci \\
\hline Cell size & $0.8-1.0 \mathrm{Um}$ \\
\hline Colony size & $10-15 \mathrm{~mm}$ \\
\hline Gram staining & Positive \\
\hline Motility & Negative \\
\hline Spore formation & Negative \\
\hline Growth in O2 & Aerobic \\
\hline Tolerance to 6.0\% NaCl & Negative \\
\hline Catalase & Positive \\
\hline Oxidase & Negative \\
\hline Gelatin liquefaction & Positive \\
\hline Nitrate reduction & Positive \\
\hline Starch hydrolysis & Negative \\
\hline Glucose, maltose, mannitol fermentation & Positive \\
\hline Utilization of citrate & Positive \\
\hline
\end{tabular}

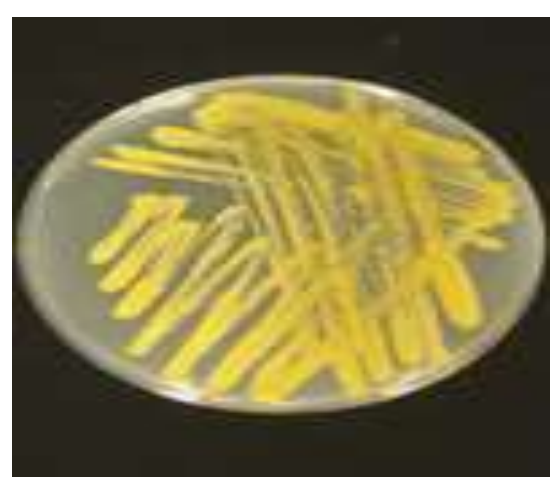

$\mathbf{A}$

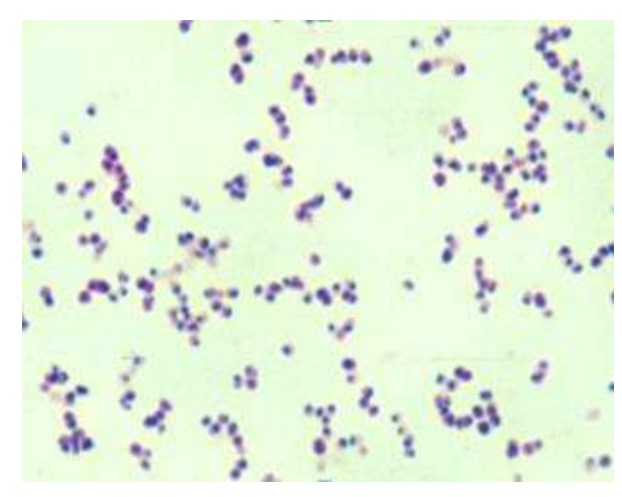

$\mathbf{B}$

Fig. (4): Colony form, (A) and microscopic examination (B) of isolate Sm2-4. 
Table (7): Growth of Rhodococcu sp. in nutrient broth medium containing three concentrations of Zn, Co and Cu metal salt.

\begin{tabular}{|l|c|c|c|}
\hline \multirow{2}{*}{ Heavy metal salt } & \multicolumn{3}{|c|}{ Concentration (ppm) } \\
\cline { 2 - 4 } & $\mathbf{2 5} \mathbf{~ p p m}$ & $\mathbf{5 0} \mathbf{~ p p m}$ & $\mathbf{1 0 0} \mathbf{~ p p m}$ \\
\hline Cu Sulfate & $1^{+}$ & - & - \\
\hline Zn Sulfate & $2^{+}$ & $2^{+}$ & - \\
\hline Co Sulfate & $2^{+}$ & $2^{+}$ & - \\
\hline
\end{tabular}

No growth (-), low grow (+) and medium growth (2+).

\subsection{Application of biosurfactants in pot experiment}

Growth parameters of tomato plants grown for 60 days as affected by heavy metals and bacterial treatments are presented in Table (8). At the beginning, tomato plants of all treatments nicely grew with no nutrient deficiency symptoms.

Plants of less than $26 \mathrm{~cm}$ in height were detected with plants left without treatment (control). Recommended fertilizers $\mathrm{N}, \mathrm{P}$, and $\mathrm{K}$ stimulated plant growth, this resulted in $38.4 \%$ increase in height of 60 day old plants. While, the plants fertilized with recommended dose of NPK and inoculated with Rhodococcus sp. as well as treated with a mixture of $\mathrm{Co}, \mathrm{Cu}$ and $\mathrm{Zn}$ sulphate 15 days after planting gave $57.1 \%$ increase in plant height when compared with the untreated ones.

Root sizes ranged from 2.2 to $6.8 \mathrm{~cm}$ depending upon treatment and plant age.

Root and shoot yields significantly increased as a result of inoculation and / or heavy metals treatment. When Rhodococcus sp. and heavy metal salts ( $25 \mathrm{ppm}$ concentration) were applied in the presence of full dose of agrochemical root and shoot dry weights achieved 84.2 and $193.3 \%$ higher than those of the control. Also, in the case of applying Rhodococcus sp. and heavy metals 15

Table (8): Tomato growth characteristics of the different treatments after 15, 30 and 60 days of planting.

\begin{tabular}{|c|c|c|c|c|}
\hline Days after planting & \multicolumn{4}{|c|}{$\begin{array}{r}\text { Treatments } \\
\end{array}$} \\
\hline & Control & $\begin{array}{l}\text { Full dose } \\
\text { of NPK }\end{array}$ & $\begin{array}{l}\text { Full dose of NPK plus } \\
\text { a mixture of } \mathrm{Cu}, \mathrm{Co} \text { and } \\
\mathrm{Zn} \text { and Rhodococcus } \mathrm{sp} .\end{array}$ & $\begin{array}{l}\text { Full dose of NPK plus, a mixture } \\
\text { of } \mathrm{Cu}, \mathrm{Co} \text { and } \mathrm{Zn} \mathbf{1 5} \text { days after } \\
\text { planting and Rhodococcus } \mathrm{sp} \text {. }\end{array}$ \\
\hline & \multicolumn{4}{|c|}{$\begin{array}{c}\text { Plant height }(\mathrm{cm} \\
\end{array}$} \\
\hline 15 & 13.50 & 17.4 & 17.0 & 19.2 \\
\hline 30 & 19.60 & 33.3 & 34.9 & 37.8 \\
\hline 60 & 25.20 & 40.9 & 54.6 & 58.7 \\
\hline \multirow[t]{2}{*}{ L.S.D. (0.05) } & \multicolumn{4}{|c|}{0.17} \\
\hline & \multicolumn{4}{|c|}{ Root size $(\mathrm{cm})$} \\
\hline 15 & 2.2 & 2.7 & 2.9 & 3.0 \\
\hline 30 & 4.3 & 5.4 & 5.8 & 5.9 \\
\hline 60 & 5.2 & 6.1 & 6.2 & 6.8 \\
\hline \multirow[t]{2}{*}{ L.S.D. (0.05) } & \multicolumn{4}{|c|}{2.96} \\
\hline & \multicolumn{4}{|c|}{ Root dry weight (g plant ${ }^{-1}$ ) } \\
\hline 15 & 0.13 & 0.14 & 0.15 & 0.19 \\
\hline 30 & 0.26 & 0.28 & 0.31 & 0.39 \\
\hline 60 & 0.38 & 0.69 & 0.70 & 0.83 \\
\hline \multirow{2}{*}{ L.S.D. (0.05) } & \multicolumn{4}{|c|}{1.87} \\
\hline & \multicolumn{4}{|c|}{ Shoot dry weight $\left(\right.$ g plant $\left.^{-1}\right)$} \\
\hline 15 & 0.72 & 0.89 & 0.90 & 0.90 \\
\hline 30 & 1.34 & 1.65 & 1.77 & 1.85 \\
\hline 60 & 1.63 & 4.36 & 4.78 & 5.25 \\
\hline \multirow[t]{2}{*}{ L.S.D. (0.05) } & \multicolumn{4}{|c|}{3.77} \\
\hline & \multicolumn{4}{|c|}{ No. leaves (per plant) } \\
\hline 15 & 20 & 28 & 29 & 30 \\
\hline 30 & 38 & 56 & 60 & 68 \\
\hline 60 & 43 & 77 & 83 & 92 \\
\hline L.S.D. (0.05) & \multicolumn{4}{|c|}{48} \\
\hline
\end{tabular}


days after planting, root and shoot dry weights showed 118.4 and $222.1 \%$ higher than those of the untreated ones.

Tomato plants bore considerable number of leaves. Plenty of these ( 83 and 92 per plant) were produced by plants received the full recommended dose of fertilization rate together with the incorporation into soil of the tested dose of the three heavy metals tested.

These results are in agreement with the data reported by Sheng et al. (2008). They reported that a pot experiment demonstrated that the application of the biosurfactant in soil contaminated with heavy metals significantly enhanced biomass of tomato plants.

In conclusion, the application of biosurfactant and biosurfactant-producing bacteria in environmental technologies (bioremediation and phytoremediation) has been studied in some researches. Also, both organic and inorganic contaminants can be removed through different processes (physico-chemical and biological) in which biosurfactants are involved. Due to their biodegradability and low toxicity, they are very promising for the use in environmental biotechnologies. The commercial success of biosurfactants is still limited due to their high production cost. Optimized growth conditions using inexpensive renewable substrates (agroindustrial wastes) and novel, efficient methods for isolation and purification of biosurfactants could make their production more economically feasible. Another important aspect regarding biological remediation technologies is the use of biosurfactant in the process on a large scale.

Little is known about the potential of biosurfactant production by microorganisms in situ. Most of the described studies were done under laboratory conditions. More efforts are required to evaluate the biosurfactant production by microorganisms in situ and their role in biological remediation technologies. More information is required concerning the structures of biosurfactants, their interaction with soil and contaminants and scale up and cost effective biosurfactant production.

Nevertheless, careful and controlled use of these interesting surface active molecules will surely help in the enhanced cleanup of the toxic environmental pollutants and provide us with a clean environment.

\section{REFERENCES}

Aşçı Y., Nurbaş M. and Açıkel Y. S. (2010).
Investigation of sorption/desorption equilibria of heavy metal ions on/from quartz using rhamnolipid biosurfactant. J. Environ. Manage., 91: 724-731.

Brenner D.J., Krieg N.R. and Staley J.T. (2005). Bergy's Manual of Systematic Bacteriology, $2^{\text {nd }}$ Ed. Springer, New York, NY, USA. 310 pp.

Dastgheib S.M.M., Amoozegar M.A., Elahi E., Asad S. and Banat I.M. (2008). Bioemulsifier production by a halothermophilic Bacillus strain with potential applications in microbial enhanced oil recovery, Biotechnol. Lett., 30: 263-270.

Franzetti A., Caredda P., Ruggeri C., La Colla P., Tamburini E., Papacchini M. and Bestetti G. (2009). Potential applications of surface active compounds by Gordonia sp. strain BS29 in soil remediation technologies. Chemosphere. 22: 117-128.

Ghayyomi Jazeh M., Forghani F. and Deog-Hwan Oh. (2012). Biosurfactan production by Bacillus sp. isolated from petroleum contaminated soils of Sirri Island. Am. J. Appl. Sci., 9 (1): 1-6.

Grainger J., Janet H. and Dariel B. (2001). Basic Practical Microbiology: A Manual. The Society for General Microbiology. $201 \mathrm{p}$.

Head I.M. and Swannell R.P.J. (1999). Bioremediation of petroleum hydrocarbon contaminants in marine habitats. Curr. Opin. Biotechnol., 10: 234-239.

Herman D.C., Artiola J.F. and Miller R.M. (1995). Removal of cadmium, lead, and zinc from soil by a rhamnolipid biosurfactant. Environ. Sci. Technol., 29: 2280-2285.

Jackson M. L. (1973). Soil chemical Analysis. Contable Co., London, UK., 325 p.

Khan J. A. and Syed H.A.R. (2011). Isolation and characterization of micro-organism from oil contaminated sites. Adv. Appl. Sci. Res., (3): 455-460.

Mulligan C.N. (2005). Environmental applications for biosurfactants. Environ. Pollut.,133: 183-198.

Neu T. (1996). Significance of bacterial surfaceactive compounds in interaction of bacteria with interfaces. Microbiol. Rev., 60: 151166.

Pacwa-Płociniczak M., Grażyna A.P., PiotrowskaSeget Z. and Cameotra S.S. (2011). Environmental applications of biosurfactants: Recent Advances. Int. J. Mol. Sci., 12: 633-654. 
Qingyi X., Mitsutoshi N., Zengshe L. and Takeo S. (2011). Biosurfactants for preparation and application. Int. J. Molecular Sci., 1422-1430.

Salihu A.,Abdulkadir I. and Almustapha M.N. (2009). An investigation for potential development on biosurfactants. Biotechnology and Molecular Biology Reviews. 3 (5): 111-117.

Sarubbo L.A. (2006). Production and stability studies of the bioemulsifier obtained from a strain of Candida glabrata UCP 1002. J. Biotechnol., 9(4): 400-406.

Sheng X., He L., Wang Q., Ye H. and Jiang C. (2008).Effects of inoculation of biosurfactant-producing Bacillus sp. J119 on plant growth and cadmium uptake in a cadmium-amended soil. J. Hazard. Mat., 155 (1-2): 17-22.

Singh P. and Cameotra S.S. (2004). Enhancement of metal bioremediation by use of microbial surfactants. Biochem. Biophy. Res. Commun., 319, 291-297.

Sneath P. H. A. (1984). Bacterial nomenclature. In Bergey's Manual of Systematic Bacteriology, vol. 1, pp. 19 \pm 23 . Edited by N. R. Krieg \& J. G. Holt. Baltimore: Williams \& Wilkins.

Snedecor G.W. and Cochran W.G. (1980). Statistical Methods. $7^{\text {th }}$ Ed. Iowa State University Press. Ames, Iowa, USA, 275 p.

Urum K. and Pekdemir T. (2004). Evaluation of biosurfactants for crude oil contaminated soil washing. Chemosphere. 57:1139-1150.

Urum K., Grigson S., Pekdemir T. and McMenamy S. (2006). A comparison of the efficiency of different surfactants for removal of crude oil from contaminated soils. Chemosphere 62:1403-1410.http:// www. microeguide. comindex. asp. Micro Guide - Aseptic techniques: Plate streaking.

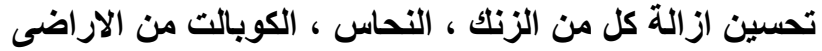

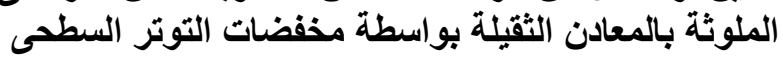

$$
\begin{aligned}
& \text { مرام ممدوح الثاهد - وليث ضياء الدين صالح - محه زكريا صديق } \\
& \text { قسم الميكروبيولوجيا الزر اعية ـ كلية الزر اعة - جامعة القاهرة - الجيزة - مصر }
\end{aligned}
$$

\begin{abstract}
ملخص

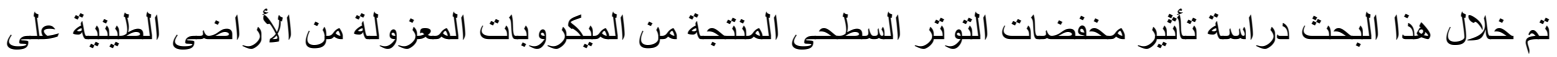

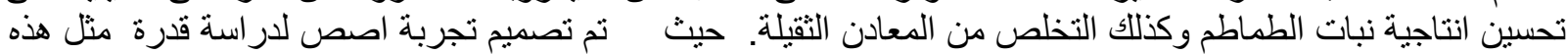

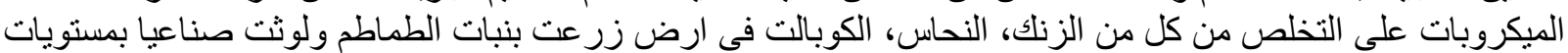

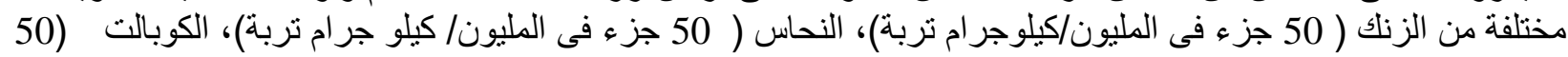
جزء فى المليون / كيلو جرام تربنة).

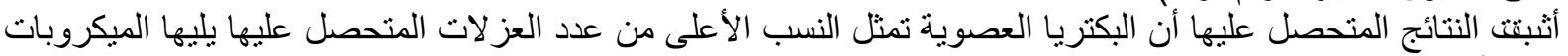
الكروية. أما بالنسبة للعصويات القصيرة السالبة لجر ام فقد جاءت في المرتبة الثالثة بالنسبة لعدد العزلات لات يليها كل من البكتريا العصوية الطويلة غير الهتجرثمة و البكتريا الخيطية.

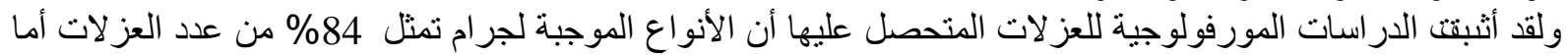

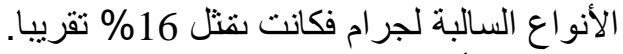

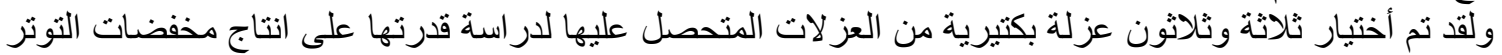

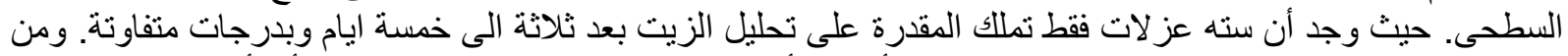

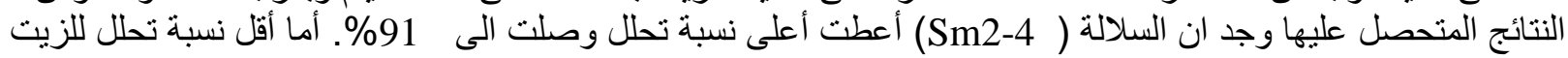
كانت للسلالة (Sm2-3). وتم ايضا در استة تاثير المعادن الثقيلة على نمو نباتات الطماطم المنماه فى تجربة أصص مع التلقيح ببكتريا rhodococcus sp. المنتجة لمخفضات التوثر السطحى بكمية كبيرة. ولقد ثبت ان التلقيح ببكتريا rhodococcus sp.

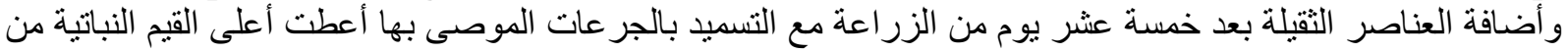

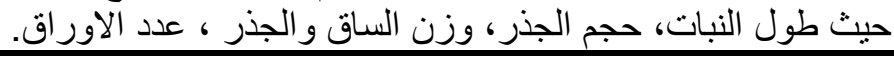

